\title{
視床出血による記憶障害の検討
}

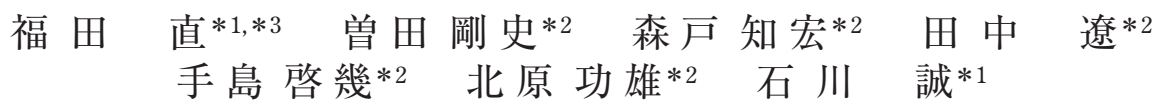

\section{Study of Amnesia Caused by Thalamic Hemorrhage}

\author{
Ataru Fukuda, ${ }^{* 1, * 3}$ Takashi Sota, ${ }^{* 2}$ Tomohiro Morito, ${ }^{* 2}$ Ryo Tanaka, ${ }^{* 2}$ \\ Yoshinori Teshima, ${ }^{* 2}$ Isao Kitahara, ${ }^{* 2}$ Makoto IshiKawA ${ }^{* 1}$
}

\begin{abstract}
Background and Purpose : Many cases of amnesia caused by thalamic hemorrhage involve anterior nucleus hemorrhage, dorsomedial nucleus hemorrhage, and intraventricular rupture. In the present study, intraventricular rupture was studied with a focus on cases with hematoma compression at the fornix. Methods : Of 116 patients with thalamic hemorrhage admitted to our hospital, 50 patients aged $<70$ years who had hemorrhage during their first stroke confined to the thalamus, internal capsule, and corona radiata, and who neither developed hydrocephalus nor showed dementia prior to onset were investigated. Thalamic hemorrhages were classified by CT findings and the extent of intraventricular rupture. Memory was studied by the FIM memory scores on admission and discharge. Results and Conclusion : Patients with dorsomedial nucleus hemorrhage showed no tendency toward amnesia and were equivalent to patients with posterolateral nucleus hemorrhage, which does not usually result in amnesia on its own. Of the 30 patients with posterolateral nucleus hemorrhage, a high degree of amnesia was observed in the 18 with intraventricular rupture. A high proportion of patients with dorsomedial nucleus hemorrhage experienced intraventricular rupture (5 of 6 patients). Equivalent degrees of amnesia were observed in patients with intraventricular rupture with dorsomedial nucleus hemorrhage and those with posterolateral nucleus hemorrhage. The present findings in conjunction with the fact that amnesia in thalamic hemorrhage involves episodic memory impairment suggest that amnesia in patients with dorsomedial or posterolateral nucleus hemorrhage or with intraventricular rupture does not stem from damage to the dorsomedial nucleus, which is part of the Yakovlev circuit involved in emotional memory. Instead, the primary cause appears to be the effects of intraventricular rupture on the Papez circuit surrounding the lateral ventricle and foramen of Monro. (Jpn J Rehabil Med 2014 ; 51 : 709-715)
\end{abstract}

要 旨 目的：視床出血による記憶障害に関しては, 前核, 背内側核出血例や，脳室穿破例 に多く, 脳室穿破による記憶障害は背内側核の障害を原因としている報告が多い. 回復期リハ ビリテーション病棟に入退院した亜急性期視床出血の記憶障害に関して検討した。方法：50 例を対象とし, 記憶に関しては入退院時の FIM の記憶項目で検討した. 結果・考察：本研究 では背内側核出血が記憶障害をきたしやすい傾向はなく後外側核出血と同等であった，後外側 核出血では 30 例中 18 例で脳室穿破しており，脳室穿破した症例で記憶障害が高度であった。 背内側核出血は 6 例中 5 例と高頻度に脳室穿破していた。脳室穿破した後外側核出血と背内側 核出血の比較でも記憶障害は同等であった。これらの結果と，視床出血による記憶障害がエピ ソード記憶障害であることから，脳室穿破症例の記憶障害の原因は，情動記憶に関与する Yakovlev 回路の一部である背内側核障害に起因したものではなく，脳室穿破したことによる 側脳室とモンロー孔周囲の Papez 回路への影響が主体ではないかと思われた。

2014 年 2 月 3 日受付, 2014 年 10 月 6 日受理

*1 船橋市立リハビリテーション病院/テ 273-0866 千葉県船橋市夏見台 4-26-1

Funabashi Municipal Rehabilitation Hospital

*2 千葉德洲会病院脳神経外科/ $=274-8503$ 千葉県船橋市高根台 2-11-1

Department of Neurosurgery, Chiba Tokushukai Hospital

*3 現在 : 千葉徳洲会病院脳神経外科

E-mail : a-fukuda@med.showa-u.ac.jp 
Key words : 記憶障害（amnesia）, 脳室穿破（intraventricular rupture）, 視床出血（thalamic hemorrhage)

\section{はじめに}

視床出血は脳出血の $25 \sim 33 \%$ を) を占め, 回復期リ ハビリテーション（以下，回復期リハ）病棟での入院 数も比較的多い疾患である．視床が解剖学的に様々な 中枢神経機能の中継点であることから，その障害によ る症状は多彩である。

発症 2 力月以内に入院する回復期リハ病棟における 覀急性期視床出血で，入院時にはすでに全般的認知は 良好で意識障害も改善しているにもかかわらず，記憶 障害が残存している症例を経験する.

視床出血重症例で, 鋳型状脳室穿破症例や, 水頭症 を認めた症例，また被殼や中脳まで血腫が拡大した症 例では意識障害が遷延することが多い。意識障害が顕 著な状態では，記憶障害の検討は不可能であり，亜急 性期である回復期では記憶障害は顕在化しなかった。 しかし，回復期リハ病棟に入院する症例は軽症例が主 体を占めていたため, その後数力月間の記憶障害回復 過程を検討することができた.

視床障害と記憶障害に関する検討はすでに数多くさ れており, Wernicke-Korsakoff syndrome から始まり， その後障害部位が系統的に分類しやすい脳梗塞で検討 され，前核，背内側核を主体とした病変に記憶障害が 多いとされている。記憶障害の根拠として，前核はエ ピソード記憶にかかわる Papez 回路の一角であるこ と，背内側核は情動記憶にかかわる Yakovlev 回路の 一角であることを挙げているものの，ともにエピソー ド記憶障害が典型的な症状とされている ${ }^{2 \sim 7)}$. 脳室穿 破を伴った視床出血が記憶障害を伴いやすいとの報告 もある．脳室穿破による記憶障害の原因としては背内 側核の障害としている ${ }^{8)}$. 背内側核出血は脳室穿破の 頻度が高いものの，出血そのものとしては頻度が低く 視床出血の $14 \%$ ぼで，脳室穿破が視床出血の $60 \%$ ほどに認められるとの報告もあるなかでは ${ }^{9)}$ ，脳室穿 破による記憶障害の原因を背内側核の障害とするのに は疑問が残る。そこで視床出血脳室穿破による記憶障 害は背内側核の障害以外に原因があるのではないかと 考えた。

脳室の解剖学的特徴から, Papez 回路で脳室穿破し
た際もっとも出血による局所圧迫を受けやすく，かつ 両側性に影響を受ける可能性のあるモンロー孔周囲の 脳弓に血腫圧迫が及んだ症例に注目し，そのことが記 憶障害の原因の 1 つではないかと仮定し検討すること とした。また computed tomography（CT）による分 類と記憶障害の有無に関しても当院の症例で検討する こととした.

\section{対象と方法}

2008 年 4 月から 2012 年 5 月までの 50 カ月間に, 当院回復期リハ病棟を入退院した視床出血 116 例のう ち, 初回脳卒中で, 血腫が視床・内包・放線冠までに 限局し, 70 歳未満で, 発症前に認知症を認めなかっ た 50 症例を対象とした.

血腫が被殸や中脳にまで達した症例は意識障害が遷 延するため回復期リハ病棟入院の段階で記憶障害を検 討するべきではないと考え，また鋳型状脳室穿破や水 頭症を発症した症例は脳室周囲全体への圧迫が強いた め生命予後が極端に悪く意識障害も遷延するため，今 回の検討からは除外した。

70 歳以上の症例が 43 例, 脳卒中の既往がある症例 が 17 例，血腫が中脳や被殼にまで及んでいたものが 8 例, 発症前から明らかな認知症の診断や精神疾患の 既往があった症例が 5 例，入院中の再発や全身疾患の 発症で転院した症例が 7 例，発症前から $\mathrm{ADL}$ で介助 を必要としていた症例が 9 例認められ, 今回の検討か らは除外した。

脳室穿破は, “側脳室＋第三脳室”, “側脳室限局”, “穿破なし”の3つの型に分類した．モンロー孔周囲 の脳弓への血腫圧迫は，“側脳室＋第三脳室”型で起 きたと想定した。CT所見から出血を前方型（Anterior type : A), 背側型 (Dorsal type : D), 後内側型 (Posteromedial type : PM), 後外側型 (Posterolateral type : PL）の 4 つの型に分類した（図 1). CT 分類でのA が前核に, PM が背内側核に相当する ${ }^{4,7)}$. 発症時の脳 実質内血腫の大きさは最大径で評価し，記憶に関して は回復期病棟入院時, 退院時の FIM 記憶項目で検討 した．麻痺の程度に関しては入院時，退院時の Brunnstrom stage score ( (上肢 + 手指 $) \times 2+$ 下肢 $/ 2)$ 


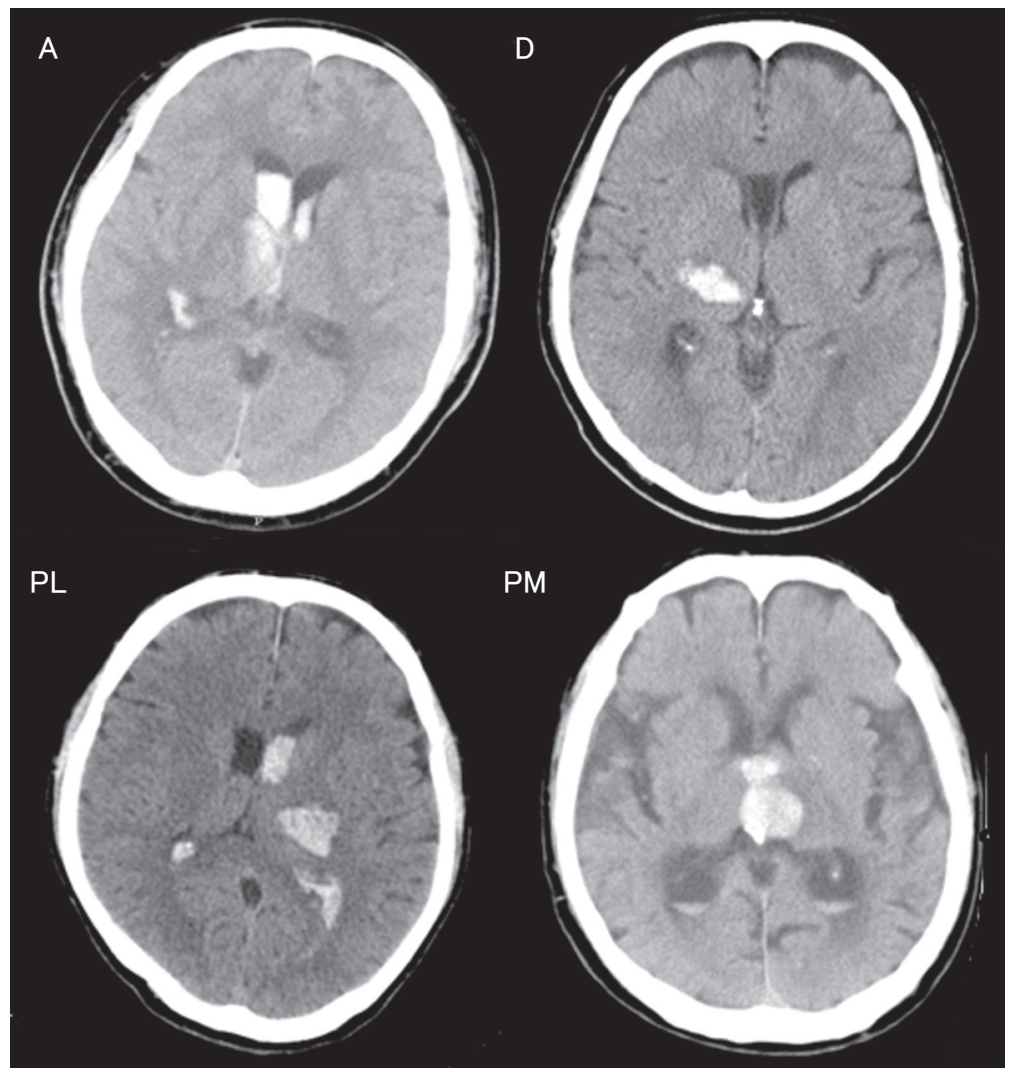

図 1 CT 分類

$\mathrm{A}$ ：極動脈還流領域の視床前部を主体に存在する出血で，度々側脳室前核に穿破す る. D : 視床の最も背側に存在する出血. PL：視床膝状体動脈還流領域の視床背 外側を主体に存在する出血で，側脳室後角から穿破することがある．PM：傍正中 動脈還流領域の視床内側を主体に存在する出血で，第三脳室に穿破することが多 い. A : 前方型 (Anterior type), D : 背側型 (Dorsal type), PL：後外側型 (Posterolateral type), PM : 後内側型（Posteromedial type）

で評価した ${ }^{8)}$.

統計学的解析はSPSS (Version 11, Chicago, IL) にて行い, Mann-Whitney U test を用いて検討し, $p<$ $0.05 \%$ で統計学的に有意と判定した.

\section{結 果}

\section{1. 対象症例の背景}

年齢は平均 60.8（38～69）歳，男性 35 人，女性 15 人. 回復期リハ病院入院日は発症から平均 28.6 （13 56）日. 回復期リ八病院入院期間は平均 94.9 （8 182）日. 右視床出血が 27 例, 左視床出血が 33 例で あった. CT 分類では A が 1 例, PM が 6 例, PLが 30 例，D が 13 例であった。脳室穿破分類では“側脳
室＋第三脳室”が 18 例，“側脳室限局”が 15 例，“穿 破なし”が 17 例であった。

\section{2. 脳室穿破分類での検討}

“側脳室＋第三脳室”, “側脳室限局”, “穿破なし” の 3 群間で入院時年齢，回復期リ八病棟入院病日，入 院期間，脳実質内の血腫量に有意差を認めなかった (図 2).FIM 記憶項目に関しては入院時の“穿破なし” と“側脳室＋第三脳室”において有意差 $(p=0.031)$ を認め, “側脳室 +第三脳室” の記憶項目点が低かっ たものの，“側脳室＋第三脳室”と“側脳室限局”に は有意差を認めなかった（入院時 $p=0.052$, 退院時 $p$ $=0.066$ ) (図 3). 
(歳)

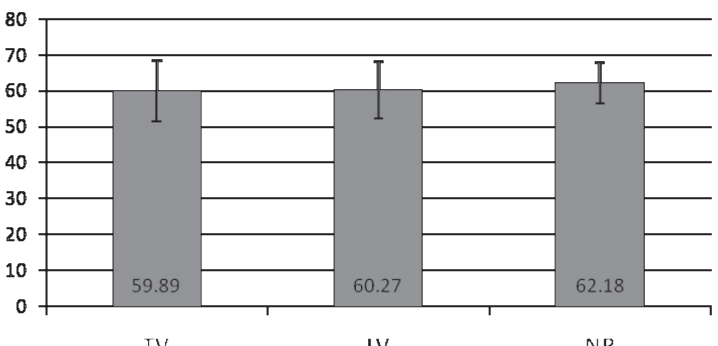

入院期間

(日)

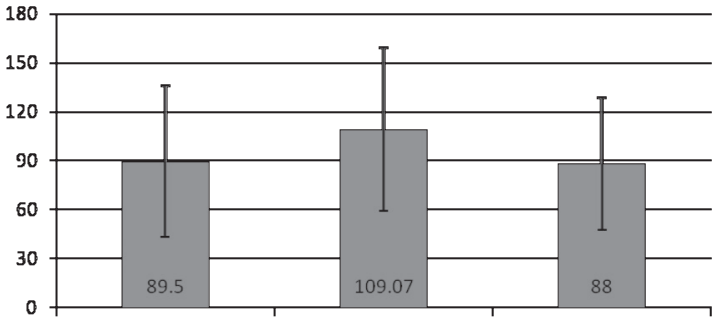

TV
LV
（日）

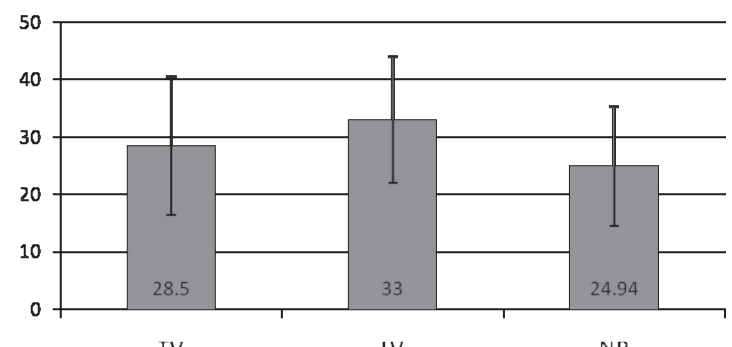

TV

LV

NR

脳実質内の血腫量

(cm)

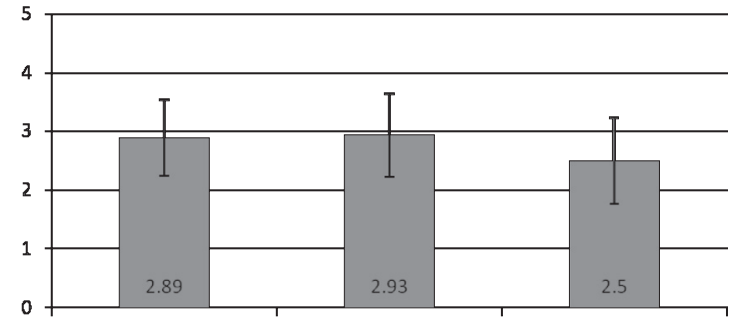

TV

NR

図 2 脳室穿破分類

“側脳室＋第三脳室”, “側脳室限局”, “穿破なし”の 3 群間で入院時年齢，回復期リ八病棟入院病日，入院期間，脳実質 内の血腫量に有意差を認めなかった. TV：“側脳室＋第三脳室” (lateral intraventricular and third intraventricular rupture), LV：“側脳室限局” (local lateral intraventricular rupture), NR：“穿破なし” (no rupture)

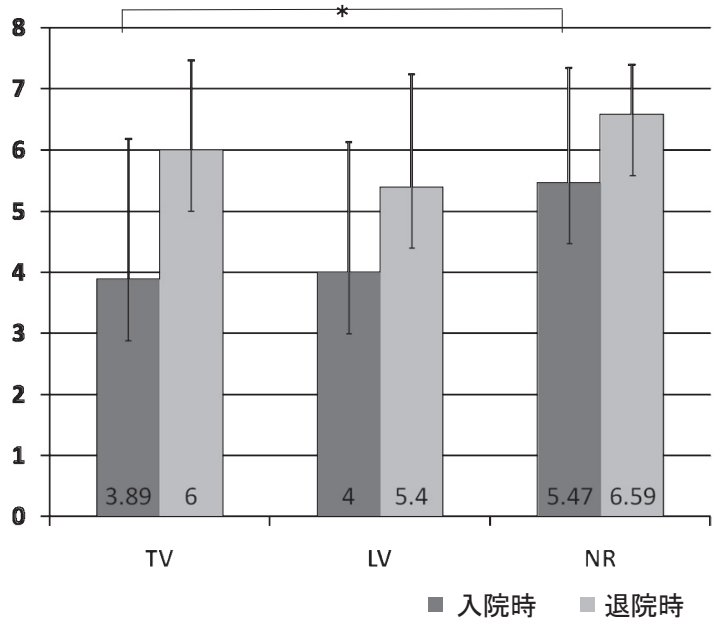

図 3 FIM 記憶項目 脳室穿破分類での検討 脳室穿破分類間での検討では，入院時の“穿破なし”と “側脳室 +第三脳室”にのみ有意差 $(p=0.031)$ を認め, “側脳室+第三脳室”の記憶項目点が低かった。*統計学 的解析はSPSS (Version 11, Chicago, IL) にて行い, Mann-Whitney U test を用いて検討し, $p<0.05 \%$ で統計学 的に有意と判定した，TV：“側脳室＋第三脳室”，LV：“側 脳室限局”，NR：“穿破なし”

\section{CT 分類での検討}

A は今回の検討では 1 症例のみだったので分析対象 とはせず，D，PL，PMの 3 群間で比較をした． 3 群 間で入院時年齢，回復期リ八病棟入院病日，脳実質内 の血腫量に有意差を認めなかった. PL と PM では, PLの入院期間が有意 $(p=0.015)$ に長期間となって おり, 入退院時の麻痺も有意（入院時 $p=0.031$, 退院 時 $p=0.006)$ に強かった（図4)。記憶に関しては, PL と PM に有意差を認めなかった（入院時 $p=0.21$, 退院時 $p=0.242 ） （$ 図 5).PLでは，脳室穿破した症 例が 18 例で, 脳室穿破していない症例が 12 例であっ た. FIM 記憶項目に関してこの 2 群間で有意差を認 め ( 入院時 $p=0.019$, 退院時 $p=0.048)$, 脳室穿破し た症例で記憶障害が高度であった。脳室穿破した PL と脳室穿破したPM の記憶障害は同等（入院時 $p=$ 0.111 , 退院時 $p=0.219 ）$ であった. 
入院時年齢

(歳)

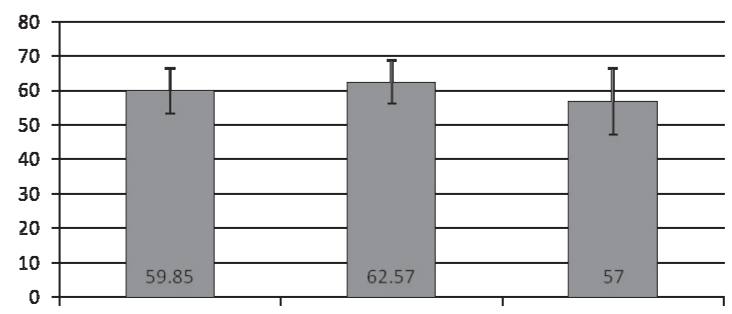

D

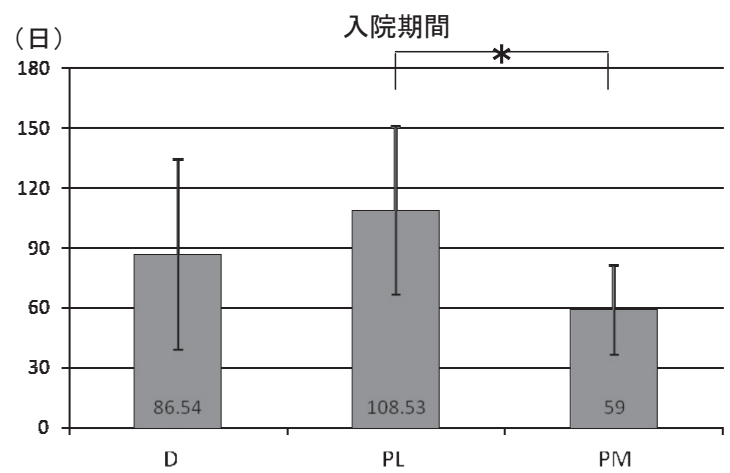

回復期リ八病棟入院病日

(日)

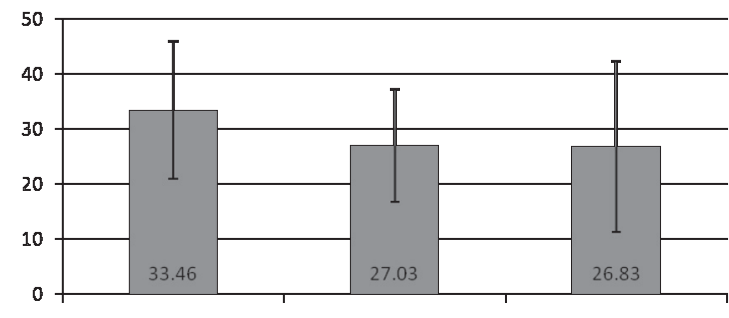

PL

PM

脳実質内の血腫量

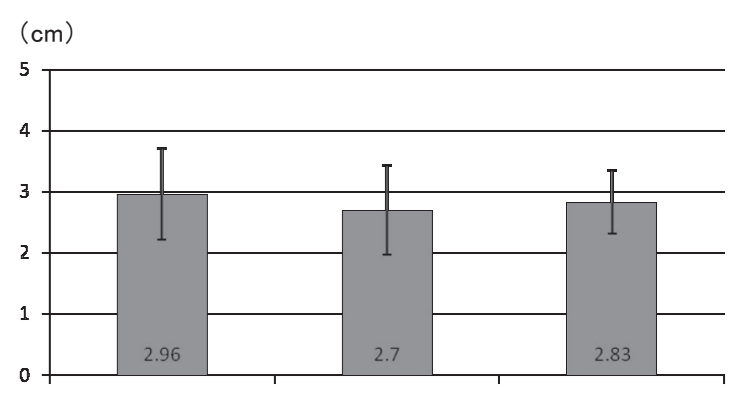

D

PL

PM

図 4 CT 分類

$\mathrm{A}$ は今回の検討では 1 症例のみだったので評価対象とはせず, D, PL, PM の 3 群間で評価をした. 3 群間で入院時年齢, 回復期リ八病棟入院病日, 脳実質内の血腫量に有意差を認めなかった。入院期間は PLが PM と比較して有意差を持って 長期間となっていた $(p=0.015)$. *統計学的解析は SPSS (Version 11, Chicago, IL) にて行い, Mann-Whitney U test を 用いて検討し， $p<0.05 \%$ で統計学的に有意と判定した. A : Anterior type, D : Dorsal type, PM : Posteromedial type, $\mathrm{PL}$ : Posterolateral type

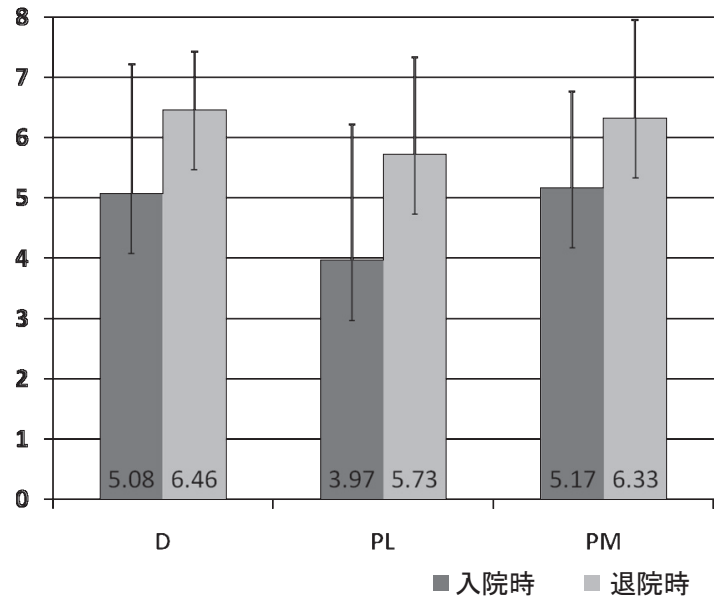

図 5 FIM 記憶項目 CT 分類での検討

CT 分類間での検討で，過去の報告で記憶障害をきたしや すいとされている $\mathrm{PM}$ が, 本研究では通常記憶障害をき たさないとされる PL と同等の記憶項目点であった（入院 時 $p=0.21$, 退院時 $p=0.242)$.

\section{考察}

\section{1. 脳室穿破分類での記憶障害に関する検討}

“側脳室＋第三脳室”に血腫が及んだ症例は，回復 期リハ病棟入院時に, “穿破なし”と比較して, 記憶 障害は有意 $(p=0.031)$ に高度であった。しかしその 記憶障害は一過性で退院時には改善傾向を認めてい た。その一方，“側脳室限局”と”側脳室＋第三脳室” では記憶障害は同等であった.

上記から，“側脳室＋第三脳室”に脳室穿破をきた すと記憶障害が高度になることは確認できたものの, “側脳室限局”との差がないことから，モンロー孔か ら側脳室周囲に存在する Papez 回路への影響により, 脳室穿破例では記憶障害をきたしやすいと思われた が，モンロー孔への血腫圧迫が記憶障害の原因である との仮定は, 本検討のみでは証明できなかった。 


\section{CT 分類での記憶障害に関する検討}

過去の報告にある前核出血は今回の検討では 1 症例 のみだったので評価できなかった。背内側核出血は過 去の報告では一過性の記憶障害を来たす報告が多いも のの ${ }^{4,7)}$, 本研究では背内側核出血と後外側核出血に おいて記憶障害は同等であった。

視床の障害による記憶障害の検討は WernickeKorsakoff syndrome から始まり，その後障害部位が 系統的に分類しやすい脳梗塞で数多く検討されてき た. 出血に関しての検討もいくつか報告されており, 前核出血は視床出血の $6 \%$ ほどと比較的まれな出血で はあるものの記憶障害は永続的になりやすいとされて おり，背内側核出血は視床出血の $14 \%$ ほどに認めら れ記憶障害は一過性で予後良好とされている。これら は視床梗塞の検討を根拠に考察がなされている ${ }^{2 \sim 7)}$. 血流支配から背内側核梗塞は両側性に障害を受けるこ とが多いが出血は通常片側性であることから，梗塞で の検討を根拠にすることは不適当と考える.

脳室穿破した症例は記憶障害をきたしやすいとさ れ，その記憶障害の根拠も背内側核障害としてい $3^{8)}$. 背内側核出血は脳室穿破の頻度が高いものの, 出血そのものとしては頻度が低く，視床出血の $14 \%$ ほどで，脳室穿破が視床出血の $60 \%$ ぼに認められ るとの報告もあるなかでは ${ }^{9)}$ ，脳室穿破による記憶障 害の原因を背内側核の障害とするのには疑問が残る。 さらに視床出血による記憶障害はエピソード記憶障害 が典型的な症状であるとしていながら，情動記憶に関 与する Yakovlev 回路の一部である背内側核を，その 根拠としていることにも疑問が残る ${ }^{2 \sim 7)}$.

本検討では背内側核出血の 6 例中 5 例，後外側核出 血の 30 例中 18 例が脳室穿破して抢り，背内側核出血 は高頻度に脳室穿破していた。後外側核出血で脳室穿 破している症例は脳室穿破していない症例と比較して 記憶障害が高度であった。また脳室穿破症例に限って 検討した場合でも，後外側核出血と背内側核出血の記 憶障害は同等であった。これらの結果から，背内側核 出血による記憶障害と脳室穿破症例の記憶障害の原因 は，ともに背内側核そのものの障害ではなく，脳室穿 破したことによる側脳室とモンロー孔周囲のPapez 回 路への影響が主体ではないかと思われた。

\section{3. 視床障害や脳弓障害による記憶障害の特徵と機構}

大脳あるいは間脳を侵す疾患であればすべて記憶障 害をきたす可能性はあるものの，具体的な病巣として
は内側側頭葉，間脳，前脳基底部，脳弓，脳梁膨大部 後方皮質などで多くの報告がある。海馬体一脳弓一乳 頭体一乳頭体視床路一視床前核一带状回一海馬傍回一 海馬体の閉鎖回路である Papez 回路は古典的記憶回 路の 1 つで，これらの構造物はそれぞれエピソード記 憶において重要な役割を果たしている10,11).

エピソード記憶は，意識に再生される記憶である陳 述記憶の長期記憶に分類される。長期記憶にはエピ ソード記憶と意味記憶があり，エピソード記憶は日々 の生活上の出来事の記憶であり, 出来事記憶や生活記 憶などと呼ばれるため，回復期リハでの主要な評価対 象となる ${ }^{10)}$.

視床病変による記憶障害は Wernicke-Korsakoff syndromeで古くから注目されており，その責任病巣と して乳頭体や視床背側核が重視されてきた。 その後虚 血性疾患での検討が数多くされており，傍正中動脈あ るいは極動脈領域の視床梗塞例がほとんどである。い ずれもエピソード記憶障害を認めるものの，傍正中動 脈閉塞はしばしば両側性に背内側核を損傷し様式特異 性（言語性，非言語性）なく前向性・逆向性ともに障 害される，極動脈閉塞では一側性に視床前核と乳頭体 視床路を損傷し，左損傷では言語性記憶障害，右損傷 では非言語性記憶障害を呈することが多いとされ $ろ^{\left.10,12^{\sim 16}\right)}$.

今回注目した脳弓による記憶障害は，海馬体と乳頭 体の連絡路であり, Papez 回路の一部を形成している ことから，エピソード記憶障害を呈するが，特に前向 性記憶障害が目立つとされている ${ }^{10,17)}$.

本検討では FIM 記憶項目を利用し，エピソード記 憶障害を生活記憶障害として評価し，前向性・逆向性 記憶障害や言語性・非言語性記憶障害の差異に関して は評価しなかった。

\section{4. 結 論}

比較的軽症で出血が中脳や被殼にまで波及せず，鋳 型状の脳室穿破や水頭症を伴わない視床出血による記 憶障害は，“穿破なし”と比較し “側脳室＋第三脳室” に血腫が及んだ症例で記憶障害が強かった。また圧迫 が原因であることから，回復期リ八病棟入院時に認め られる発症 2 力月以内の記憶障害は，回復期リ八病棟 を退院する発症 8 力月以内に改善することが多かっ た。

しかし脳室穿破症例のなかで，“側脳室＋第三脳室” と“側脳室限局”には記憶障害の有意な差は認められ 
ず，Monro 孔周囲の脳弓への血腫圧迫が記憶障害の 原因であるとの仮定に関しては，更なる症例の積み重 ねと検討が必要であると思われた。

記憶障害をきたしやすいとされている背内側核出血 に関しては，本研究では後外側核出血と同等であっ た。過去の報告では，記憶障害の根拠を両側性に障害 を受ける背内側核梗塞での検討としていた。エピソー ド記憶障害が典型症状でありながら背内側核は情動記 憶に関与する Yakovlev 回路の一部であること，記憶 障害を通常きたさない後外側核出血と記憶障害が同等 であったこと，背内側核出血は脳室穿破を高頻度にお こすことから，背内側核出血の記憶障害の原因は核そ のものの障害より，むしろ脳室穿破したことによる側 脳室とモンロー孔周囲の Papez 回路への影響が主体 ではないかと思われた。

\section{文献}

1）松谷雅生,田村 晃: 脳神経外科 周術期管理のすべ て.メディカルビュー社, 東京, 2000

2) Alexander GE, DeLong MR, Strick PL : Parallel organization of functionally segregated circuits linking basal ganglia and cortex. Annu Rev Neurosci 1986 ; 9 : 357381

3) Choi D, Sudarsky L, Schachter S, Biber M, Burke P : Medial thalamic hemorrhage with amnesia. Arch Neurol $1983 ; 40: 611-613$

4) Chung CS, Caplan LR, Han W, Pessin MS, Lee KH, Kim JM : Thalamic hemorrhage. Brain 1996 ; 119 : 1973-1886

5) Hankey GL, Stewart-Wynne EG : Amnesia following thalamic hemorrhage. Stroke $1988 ; 19: 776-778$

6) Ikeda $\mathrm{K}$, Yamashita $T$, Uno E, Yamamoto $S$, Ito $H$, Tsuchiya Y : Clinical manifestations of small thalamic hemorrhage. Brain Nerve 1985 ; 37 : 173-179

7) Kawahara N, Sato K, Muraki M, Tanaka K, Kaneko M, Uemura $\mathrm{K}$ : CT classification of small thalamic hemorrhage and their clinical implications. Neurology 1986 ; $36: 165-172$

8) Mori S, Sadoshima S, Ibayashi S, Fujishima M, Iino K : Impact of thalamic hematoma on six-month mortality and moor and cognitive functional outcome. Stroke 1995 ; $36: 62-66$

9) 石原秀行, 國次一郎, 鈴木倫保, 金 大成: 脳室穿破, 水 頭症の頻度と出血部位,危険因子との関係（小林祥泰 編). 脳卒中データバンク.中山書店, 東京, 2009 ; pp 142-143

10) 菊池大一, 藤井俊勝: 高次脳機能障害各論 7 . 記憶障害A. 記憶障害一概論. 神経内科 $2008 ; 68$ (Suppl. 5)：484493

11) Mayes AR : Effects on memory of Papez circuit lesions. in Handbook of Neuropsychology (ed by Boller F, Grafman J).2nd Ed. Elsevier, Amsterdom, 2000 ; pp $111-131$

12) Victor $M$ : The amnesic stndrome and its anatomical basis. Can Med Assoc J 1969 ; 100 : 1115-25

13）森 悦郎：視床性健忘. 臨床精神医学講座S 2 記憶の臨 床 (浅井昌弘, 鹿島晴雄 編).中山書店, 東京, 1999 ; pp 193-204

14) Castaigne P, Lhermitte F, Buge A, Escourolle R, Hauw JJ, Lyon-Caen $\mathrm{O}$ : Paramedian thalamic and midbrain infarct : clinical and neuropathological study. Ann Nurol $1981 ; 10: 127-148$

15) Ghika-Schmid F, Bogousslavsky J : The acute behavioral syndrome of anterior thalamic infarction : a prospective study of 12 cases. Ann Neurol $2000 ; 48: 220-227$

16) 高橋昭喜 : 脎MRI 1. 正常解剖. 第 2 版. 秀潤社, 東京, 2005

17) Sweet WH, Talland GA, Ervin FR: Loss of recent memory following section of fornix. Trans Am Neurol Assoc $1959 ; 84: 76-82$ 